\title{
Impact of improved bottom hypoxia on zooplankton community in shallow eutrophic lake
}

\author{
Kwang-Hyeon Chang(1),^, Hiroyuki Imai(2), Kazuhiro Ayukawa(3), \\ Shogo Sugahara ${ }^{(3)}$, Shin-ichi Nakano ${ }^{(4)}$, Yasushi Seike ${ }^{(3)}$ \\ Received September 7, 2012 \\ Revised January 24, 2013 \\ Accepted January 25, 2013
}

Key-words:
oxygen
condition,
hypoxia,
zooplankton,
copepod,
brackish lake

\section{ABSTRACT}

\begin{abstract}
We followed changes in the abundance of meso- and microzooplankton after an existing bottom hypoxia improved by the introduction of water with high oxygen content into the bottom. Mesozooplankton, calanoid copepod Acartia hudsonica showed ten times higher abundance under high oxygen condition at the bottom than under control where there was less oxygen at the bottom. On the other hand, during summer when microzooplankton such as rotifers and small cyclopoid species Oithona spp. were dominant, no difference in their distribution pattern and abundance was observed. Results have suggested that oxygen concentration at the bottom is one important factor determining the abundance and distribution of mesozooplankton even in local-scale probably by providing bottom refuge, but not for microzoooplankton. Since spring season is important for recruitment of many commercial fish juveniles, the distribution of oxygen in the lake seems very important for the fish stock in the lake.
\end{abstract}

\section{RÉSUMÉ}

L'impact de la correction de l'hypoxie benthique sur la communauté de zooplancton dans un lac eutrophe peu profond

Mots-clés:
oxygénation,
hypoxie,
zooplancton,
copépode,
lac saumâtre

Mots-clés :

Nous avons suivi les changements dans l'abondance des méso- et microzooplanctons après une correction de l'hypoxie benthique par l'introduction d'eau à forte teneur en oxygène dans le fond. Le mésozooplancton, copépode calanoïde Acartia hudsonica, a présenté une abondance dix fois plus élevée, dans des conditions de haute teneur en oxygène sur le fond, que dans une zone témoin où il y a moins d'oxygène au fond. D'autre part, pendant l'été lorsque le microzooplancton tel que les rotifères et les petites espèces cyclopoïdes Oithona spp. sont dominantes, aucune différence dans leur mode de distribution et l'abondance n'a été observée. Les résultats suggérent que la concentration en oxygène au fond est un facteur important pour déterminer l'abondance et la distribution de mésozooplancton même à l'échelle locale probablement en fournissant un refuge, mais pas pour le microzoooplankton. Comme la saison du printemps est importante pour le recrutement de nombreux jeunes poissons commerciaux, la distribution de l'oxygène dans le lac semble très importante pour les stocks de poissons dans le lac.

(1) Department of Environmental Science and Engineering, Kyung Hee University, 1732 Deokyoungdae-ro, 446-701 Yongin-Si, Republic of Korea

(2) Center for Marine Environmental Studies, Ehime University, 2-5 Bunkyo-cho, 790-8577 Matsuyama, Japan

(3) Faculty of Science and Engineering, Shimane University, 1060 Nishikawatsu-cho, 690-8504 Matsue, Japan

(4) Center for Ecological Research, Kyoto University, 509-3, 2-chome, 520-2113 Otsu, Japan

* Corresponding author: chang38@khu.ac.kr 


\section{INTRODUCTION}

Hypoxia (low oxygen water, $<2 \mathrm{mg} \cdot \mathrm{L}^{-1}$ dissolved oxygen) mainly caused by eutrophication, has become a worldwide problem not only in freshwater ecosystems but also in estuarine and coastal areas (Diaz and Rosenberg, 2008; Jin et al., 2008). It has been suggested that low oxygen concentration directly restricts the distribution of various aquatic organisms, from zooplankton to fish (Ekau et al., 2009). With regard to zooplankton community, many field observations have shown that the oxygen concentration plays an important role in determining the distribution and seasonal succession of zooplankton species. The main impacts of hypoxia on zooplankton community can be summarized as 1) modification of species composition due to species-specific differences in the resistance against low oxygen and 2) variations in the vertical and horizontal distribution of low oxygen-vulnerable species in the habitat (Uye, 1994; Zhang et al., 2009). However, strong experimental evidence that can prove the direct impact of low oxygen condition on zooplankton community is still lacking and the impacts of hypoxia on pelagic organisms in costal marine and lake systems remain largely enigmatic (Vanderploeg et al., 2009). Especially, knowledge on the effect of improved hypoxia on zooplankton community in natural habitats is quite necessary, not only for the management of water quality and fisheries resources but also for ecological understanding on how eutrophication and hypoxia is affecting the structure and function of aquatic ecosystems.

Recently, various environmental engineering techniques are being applied to improve the benthic oxygen level of eutrophicated lake ecosystems. Matsue Doken Inc. and the Japan Public Works Research Institute have developed a submerged type of hypolimnetic oxygenator, called a Water Enviornmental Preservation System (WEP, Matsue Doken Co., Ltd., Japan), and it has been applied to highly eutrophicated lakes and reservoirs in Japan. The operation of WEP increased dissolved oxygen concentration and maintained high oxygen concentration in the tested aquatic ecosystems (Yajima et al., 2009). The successful application of the system can provide a chance to observe how the zooplankton community responds to different oxygen levels in the natural habitat. We estimated the impacts of improved bottom oxygen condition on seasonal succession and local-scale distribution of micro- and mesozooplankton by comparing WEP system operated site and a near-by control site.

\section{MATERIALS AND METHODS}

Lake Naka-umi $\left(35^{\circ} 45^{\prime} \mathrm{N}, 133^{\circ} 11^{\prime} \mathrm{E}\right.$, Shimane Prefecture, Japan) is a shallow brackish lake, which has been suffered from serious eutrophication by anthropogenic nutrient influx from the surrounding agricultural and urban areas. The oxygen deficiency in lake bottom was accelerated in accordance with eutrophication, and its impacts on lake organisms had been frequently reported (Ishitobi et al., 2000; Uye et al., 2004; Katsuki et al., 2008). To improve the benthic oxygen level and to evaluate the chemical and biological responses to elevated oxygen levels in the bottom, high pressure oxygen injecting system, WEP system was set up at the eastern part of the lake (Figure 1). The system was operated from May to October 2009 when hypoxia occurred, and responses of water quality and biota were monitored. The operation increased dissolved oxygen concentration and maintained oxygen concentration as $5-15 \mathrm{mg} \cdot \mathrm{L}^{-1}$ nearby the outlet of WEP system in the lake (Masuki et al., 2011).

Vertical distributions of water temperature, salinity and dissolved oxygen (DO) concentration were monitored every month from May to November 2009 both at the point approximately $50 \mathrm{~m}$ away from the WEP system (oxygen treated site) and at a point approximately $250 \mathrm{~m}$ away from the system (control site). Vertical distribution ( $1 \mathrm{~m}$ depth interval) of phytoplankton biomass (Chlorophyll a concentration) was measured using a fluorometer (10-AU, Turner Designs) following Moran and Porath (1980). Zooplankton was collected during the same period of WEP operation (until October). Microzooplankton was collected by filtering the water samples collected at 1, 3, 7 and $13 \mathrm{~m}$ depth using Van Dorn sampler (6 L), through $60 \mu \mathrm{m}$ mesh net. Mesozooplankton was collected by vertical towing of the $200 \mu \mathrm{m}$ mesh net. Two vertical replicate samples for each treated and control site were collected in May, and three replicates 


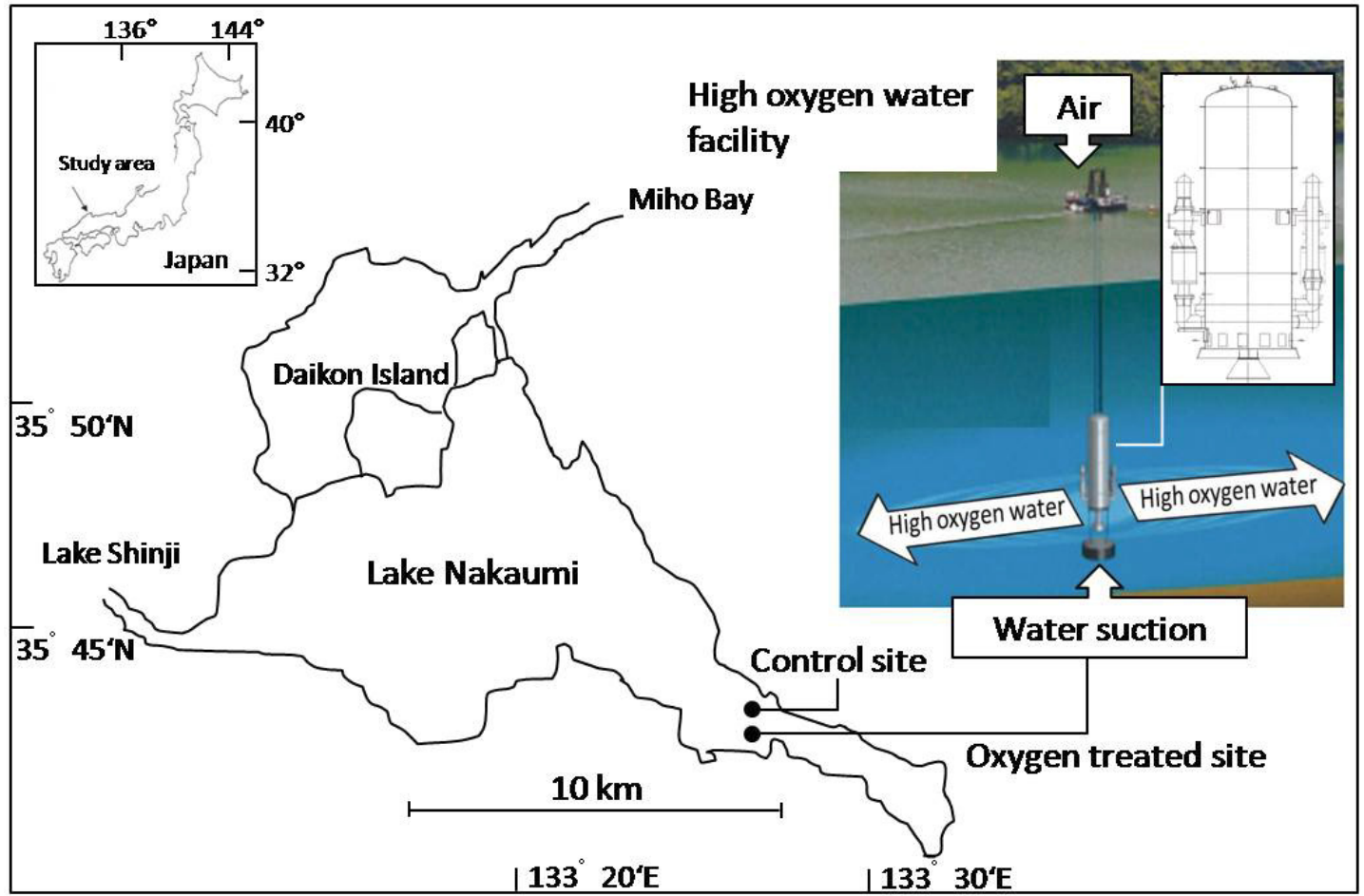

Figure 1

Map of study site and high pressure oxygen injecting system (Water Environmental Preservation system, WEP).

were collected thereafter. The comparisons of environmental parameters and zooplankton abundances at the two sites were made by paired $t$-test or Wilcoxon signed-rank test according to distribution using R v. 2.11.0 (R Foundation for Statistical Computing, Vienna).

\section{RESULTS}

Investigated environmental parameters showed no apparent differences between the two sites except the vertical distribution of DO (Figure 2). Temperature stratification was observed from June to July, and surface water temperature increased to maximum $\left(30^{\circ} \mathrm{C}\right)$ in August. Strong salinity stratification was observed throughout the study period. Phytoplankton was found to be higher in shallow areas above $5 \mathrm{~m}$ depth. Chlorophyll a concentration below $5 \mathrm{~m}$ was lower than $5 \mu \mathrm{g} \cdot \mathrm{L}^{-1}$. There was no statistical difference with depth in the vertical distribution of temperature, salinity and chlorophyll a concentration (Wilcoxon signed rank test, $P>0.05)$. On the other hand, introduction of high oxygen water increased bottom layer oxygen concentration to higher than $10 \mathrm{mg} \cdot \mathrm{L}^{-1}$ throughout the study period. However, high oxygen concentration disappeared after WEP was stopped. During all the experimental months, DO concentration at deeper than $10 \mathrm{~m}$ was significantly higher in oxygen treated site (paired t-test, $p<0.05$ ).

Throughout the study period, Acartia sinjiensis, Acartia hudsonica, Cosmocalanus darwinii, Paracalanus spp. and Oithona spp. were detected. However, only A. hudsonica and Oithona spp. showed high abundances, and other species appeared sporadically. They showed reciprocal succession pattern, showing high abundance of Acartia in Spring (May) but high abundance of Oithona spp. during summer (Figure 3). Particularly in May, Acartia hudsonica in oxygen treated site showed about ten times higher abundance than the control site (Figure 4). During the sampling date the DO at bottom $(15 \mathrm{~m})$ was $3.48 \mathrm{mg} \cdot \mathrm{L}^{-1}$ at oxygen 


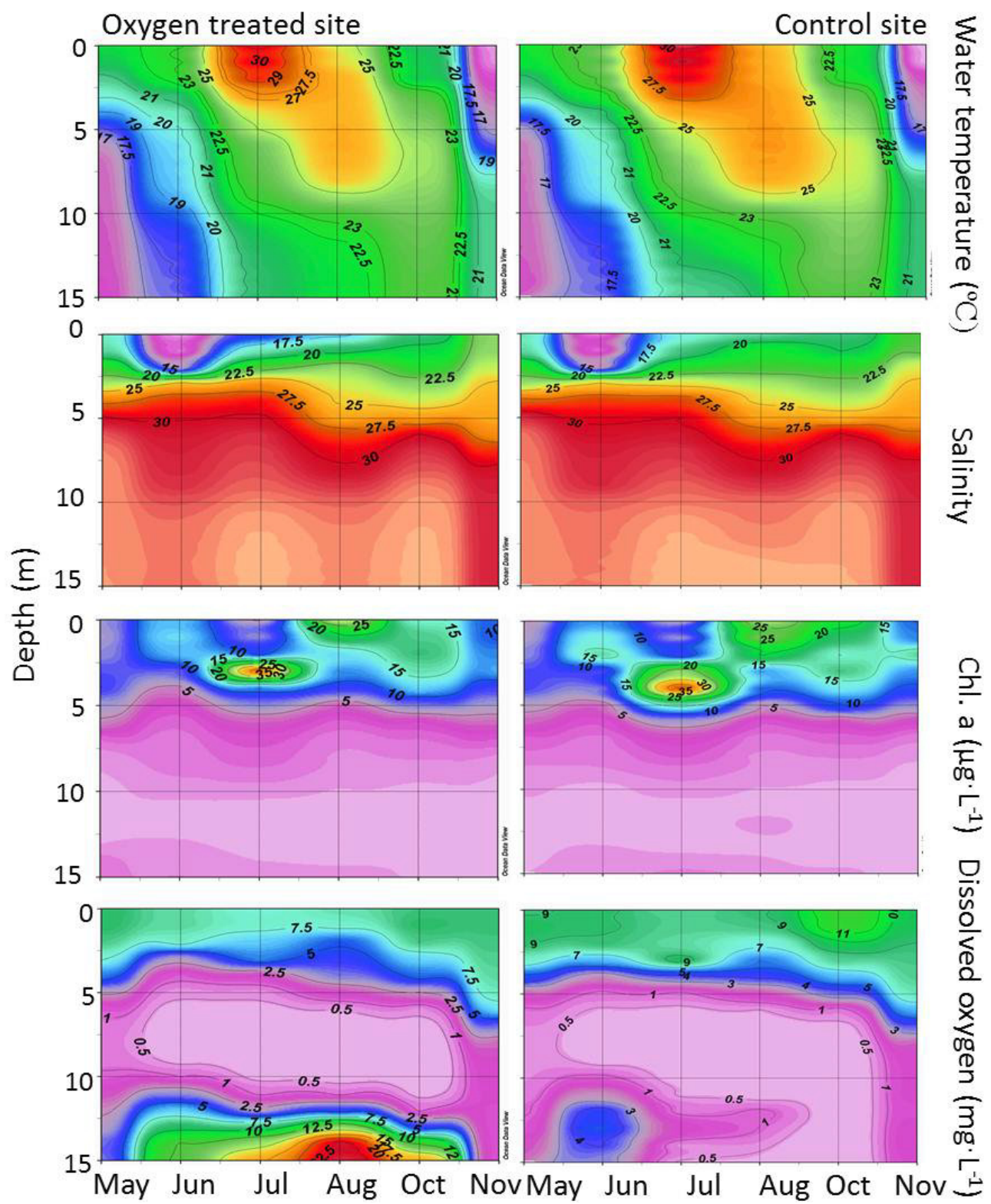

Figure 2

Vertical profiles of water temperature, salinity, phytoplankton biomass (Chlorophyll a concentration) and dissolved oxygen concentration at oxygen treated and control sites during the study period (May to November).

treated site and $1.71 \mathrm{mg} \cdot \mathrm{L}^{-1}$ at the control site, and most water column below $5 \mathrm{~m}$ had DO concentration lower than $1 \mathrm{mg} \cdot \mathrm{L}^{-1}$ at control site (Figure 2). However, Acartia was rarely found thereafter and Oithona spp. dominated copepod community during summer. Oithona spp. showed higher average density at oxygen treated site, but statistical difference was not found.

Microzooplankton mainly consisted of rotifers (Synchaeta sp. and Brachionus urceolaris), Oithona spp. (mainly copepodid stages) and copepod nauplii. Their abundance increased from July to August, and they were higher in shallow layers (shallower than $6 \mathrm{~m}$ ) and low abundance was observed in deeper layers (Figure 5). Their distribution showed no relationship with elevated DO level in oxygen treated site and no significant difference was found in their vertical distribution (Wilcoxon signed rank test, $p>0.05$ ). 


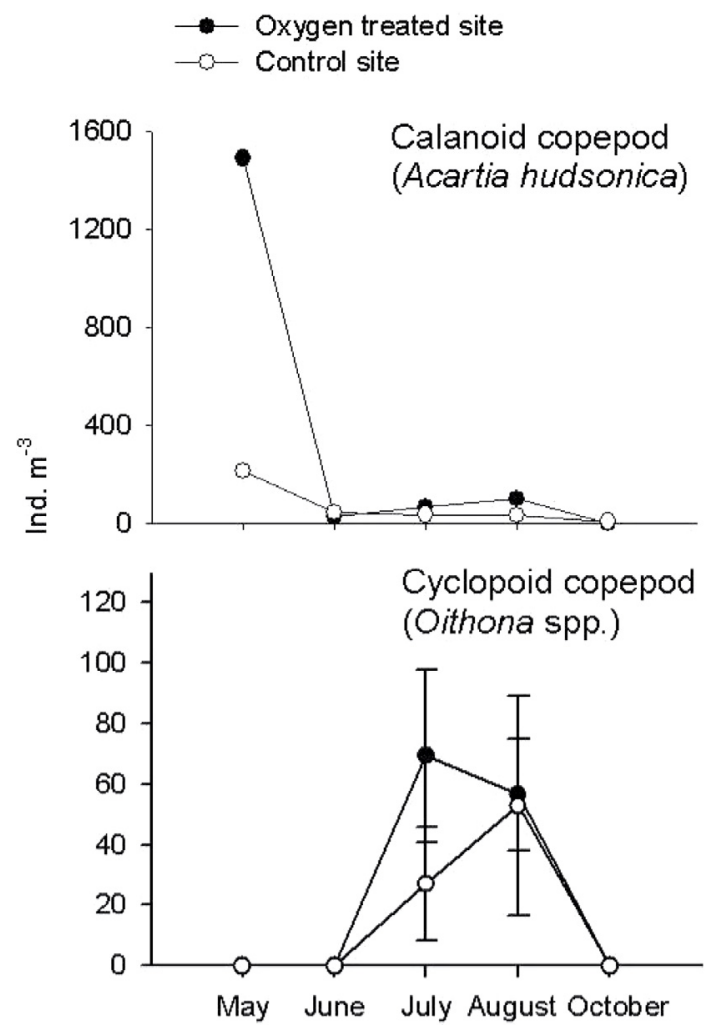

Figure 3

Seasonal changes of mesozooplankton (mean \pm standard deviation) at oxygen treated and control sites during the sampling period (May to October).

\section{Figure 4}

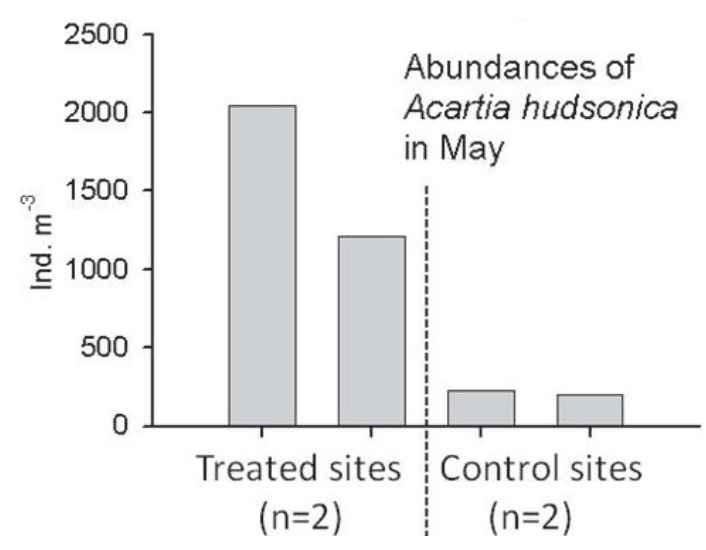

Comparison of Acartia hudsonica abundances at oxygen treated and control sites in May.

\section{DISCUSSION}

The difference of abundance of zooplankton by improvement of the bottom was observed only in May when A. hudsonia became dominant. A. hudsonica and Oithona spp. showed clear reciprocal succession pattern with dominance of $A$. hudsonica in spring and that of Oithona spp. in summer. This pattern coincides with previous findings reported by Ohtsuka et al. (1999) and Uye et al. (2004) that $A$. hudsonica dominates copepod community from winter to spring while Oithona davisae did from summer to fall in Lake Naka-umi. However, these previous studies showed that copepod abundances, particularly those of calanoids were highly variable within the lake as well as in the nearby lakes. Uye et al. (2000) suggested 


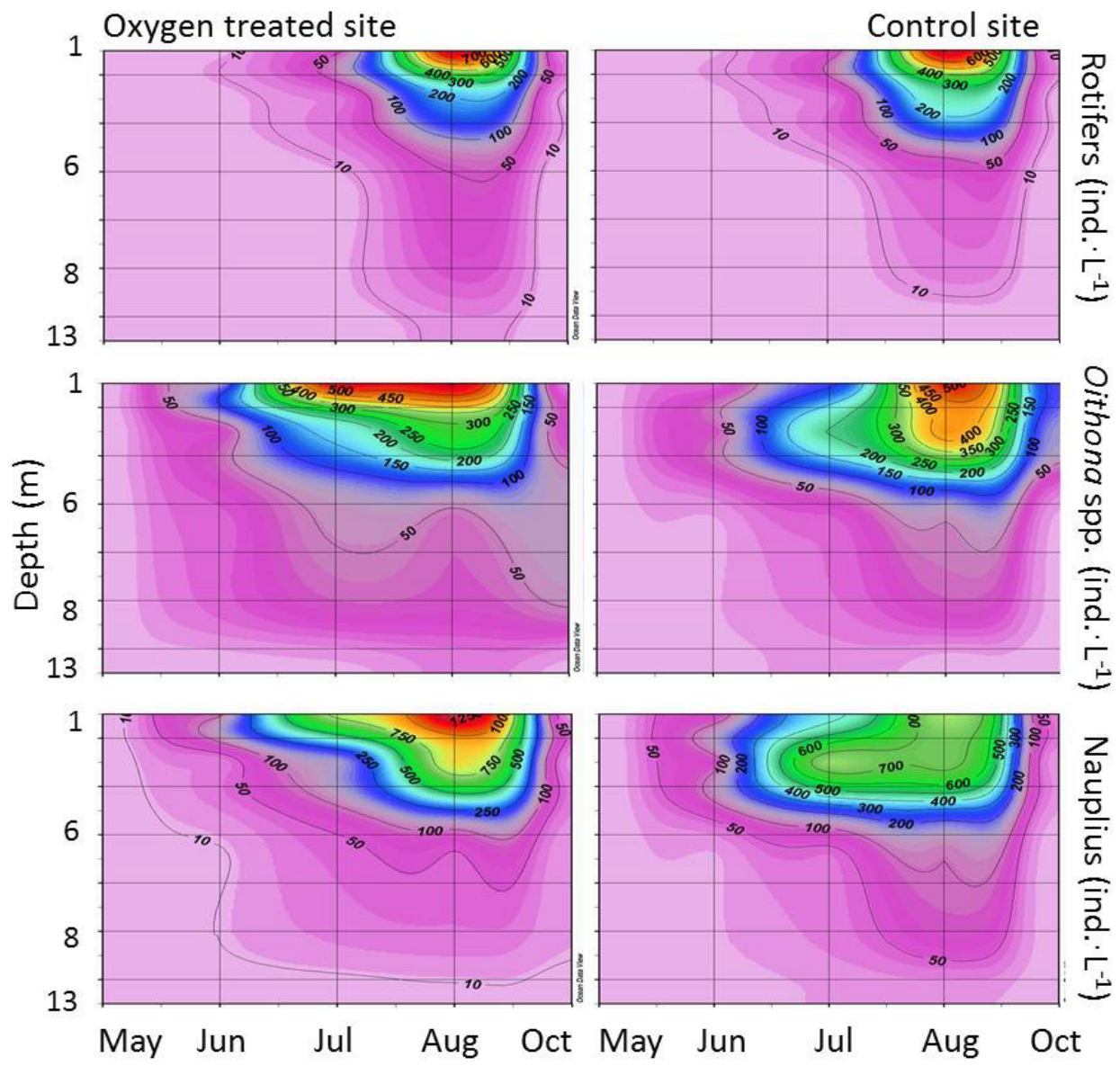

Figure 5

Seasonal changes in vertical distribution of microzooplankton at oxygen treated and control sites during the sampling period (May to October).

that such a difference is closely related to oxygen levels, with a coincidence of high copepod abundance and high oxygen level in the water column. The two sites examined in the present study were just $250 \mathrm{~m}$ away from each other, and showed very similar chemical and physical conditions except DO concentration in the bottom. Our results by the direct comparison of the two sites provide strong evidence that oxygen condition is very important factor determining the copepod abundance in spring. In other words, bottom hypoxia suppresses the copepod density, and induces local-scale heterogeneous distribution of zooplankton community.

Since we collected copepod using vertical net towing and did not analyze their vertical distribution patterns, we could not estimate the mechanism, how improved bottom oxygen level induced high density of $A$. hudsonica. However, it is very clear that elevated oxygen level at the bottom induces high abundance of copepod during spring. Chlorophyll a concentration was higher near surface and scarce below $5 \mathrm{~m}$ depth at both sites. DO concentrations were low between $5 \mathrm{~m}$ and $10 \mathrm{~m}$ depth at both sites. Thus, one possible interpretation is that the bottom area with more oxygen can be used as refuge for copepods to avoid fish predation. A. hudsonica carries out vertical migration in response to fish abundance, and they stay in deeper area during daytime (Bollens et al., 1994). However, at the same time, genus Acartia are not resistant to low oxygen condition lower than $1 \mathrm{mg} \cdot \mathrm{L}^{-1}$ (Stalder and Marcus, 1997). Considering high fish abundance in Lake Naka-umi (Ishitobi et al., 2000), Acartia sp. prefers to take refuge in the bottom area with DO levels enough for their survival.

Unlike in the case of mesozooplankton, there was no difference in microzooplankton including rotifers and small cyclopoid, Oithona spp. They were abundant near surface and it is not likely that they are affected by hypoxia in bottom area. In summer, species composition of 
Lake Naka-umi changes totally with dominance of smaller species, it seems that oxygen improvement do not have apparent impact on zooplankton community in summer. It can be concluded that in Lake Naka-umi, zooplankton community showed species-specific responses to oxygen improvement in bottom, and consequently, its impact was apparent only in spring when mesozooplankton was dominant. Juveniles of a many fish species depend on mesozooplankton in spring as important food source that helps in the intensive mass seed production of finfish, sea bream, Japanese flounder and ayu in Lake Naka-umi (Uye et al., 2004). Although improvement of bottom oxygen condition in the lake affects only the calanoid, Acartia in spring, it can be expected that the increase of zooplankton biomass affects fisheries positively in this lake. At the same time, long-term and large-scale survey on the relationship between improvement of hypoxia and ecosystem health as well as the efficiency of oxygen introduction and fisheries have to be considered in future studies.

\section{ACKNOWLEDGEMENTS}

The authors appreciate Dr. A. Suburamanian for critical reading of the manuscript. This study was supported by a Grant-in-Aid from the Ministry of Education, Science, Sport and Culture, Japan, to Seike Y. (No. 19202016).

\section{REFERENCES}

Bollens S.M., Frost B.W. and Cordell J.R., 1994. Chemical, mechanical and visual cues in the vertical migration behavior of the marine planktonic copepod Acartia hudsonica. J. Plankton Res., 16, $555-564$.

Diaz R.J. and Rosenberg R., 2008. Spreading dead zones and consequences for marine ecosystems. Science, 321, 926-929.

Ekau W., Auel H., Pörtner H.O. and Gilbert D., 2009. Impacts of hypoxia on the structure and processes in the pelagic community (zooplankton, macro-invertebrates and fish). Biogeosci. Discuss., 6, 5073-5144.

Ishitobi Y., Hiratsuka J., Kuwabara H. and Yamamuro M., 2000. Comparison of fish fauna in three of adjacent eutrophic estuarine lagoons with different salinities. J. Mar. Syst., 26, 171-181.

Jin X., Lu S., Hu X., Jiang X. and Wu F., 2008. Control concept and countermeasures for shallow lakes' eutrophication in China. Front. Environ. Sci. China, 2, 257-266.

Katsuki K., Miyamoto Y., Yamada K., Takata H., Yamaguchi K., Nakayama D., Coops H., Kunii H., Nomura R. and Khim B.K., 2008. Eutrophication-induced changes in Lake Nakaumi, southwest Japan. J. Paleolimnol., 40, 1115-1125.

Masuki S., Yajima H. and Seike Y., 2011. Injection of highly oxygenated water into the bottom of dredged area in Lake Nakaumi. J. JSCE Ser. B1 (Hydraulic Engineering), 67, 1525-1530.

Moran R. and Porath D., 1980. Chlorophyll determination in intact tissues using N, N-dimethylformamide. Plant Physiol., 65, 478-479.

Ohtsuka S., Hoshina T., Seike Y., Ohtani S. and Kunii H., 1999. Seasonal changes of zooplankton community in Honjyo area and its neighboring waters of Lake Naka-umi. LAGUNA, 6, 73-87.

Stalder L.C. and Marcus N.H., 1997. Zooplankton responses to hypoxia: hebavioral patterns and survival of three species of calanoid copepods. Mar. Biol., 127, 599-607.

Uye S., 1994 Replacement of large copepods by small ones with eutrophication of embayments: cause and consequence. Hydrobiologia, 292-293, 513-519.

Uye S., Nakai S. and Aizaki M., 2004. Potential use of extremely high biomass and production of copepods in an enclosed brackish water body in Lake Nakaumi, Japan, for the mass seed production of fishes. Zool. Stud., 43, 165-172.

Uye S., Shimazu T., Yamamuro M., Ishitobi Y. and Kamiya H., 2000. Geographical and seasonal variations in mesozooplankton abundance and biomass in relation to environmental parameters in Lake Shinji-Ohashi River-Lake Nakaumi brackish-water system, Japan. J. Mar. Syst., 26, 193-207. 
Vanderploeg H.A., Ludsin S.A., Cavaletto J.F., HööK T.O., Pothoven S.A., Brandt S.B., Liebig J.R. and Lang G.A., 2009. Hypoxic zones as habitat for zooplankton in Lake Erie: refuges from predation or exclusion zones? J. Exp. Mar. Biol. Ecol., 381, S108-S120.

Yajima H., Imberger J. and Dallimore C., 2009. Evaluation of the intrusion generated by a submerged contact chamber of hypolimnetic oxygenator in a reservoir. Int. J. River Basin Management, 7, 415-422.

Zhang H., Ludsin S.A., Mason D.M., Adamack A.T., Brandt S.B., Zhang X., Kimmel D.G., Roman M.R. and Boicourt W.C., 2009. Hypoxia-driven changes in the behavior and spatial distribution of pelagic fish and mesozooplankton in the northern Gulf of Mexico. J. Exp. Mar. Biol. Ecol., 381, S80-S91. 